\title{
伏在型静脈瘤に対する血管内レーザー焼灼術における 側枝静脈瘤切除の必要性の有無の検討
}

\author{
平林朋子佐野 成一高島格
}

\begin{abstract}
要約：【はじめに】今回われわれは伏在型静脈瘤で瘤切除を行わずに伏在静脈の血 管内レーザー焼灼術のみを行った症例で瘤切除の必要性の有無を検討した.【対象と方 法】2013 年 1 月から 4 月の間に一次性の伏在型静脈瘤患者 98 名 108 肢 (男：女比 $42: 56$, 平均年齢 68 歳, 大伏在静脈 91 本, 小伏在静脈 17 本, 大伏在静脈平均径 $6.5 \pm 1.5 \mathrm{~mm}$, 小 伏在静脈平均径 $5.9 \pm 1.4 \mathrm{~mm}$, 平均最大側枝径 $5.4 \pm 2.6 \mathrm{~mm}$ ) において瘤切除は追加せず伏在 静脈に血管内レーザー焼灼術を施行し結果を検討した. 術前および術後 2 カ月後に評価 した.【結果】側枝の完全縮小群は 11 肢の $10.2 \%$, 部分縮小群は 97 肢の $89.8 \%$, 無変化 群は 0 肢だった。部分縮小群抢よび無変化群で追加治療を行ったのは 7 肢 $(6.5 \%)$ ですべ ての症例で整容的理由からであった、【結語】多くの症例が, 術後 2 カ月の時点で伏在静脈 本幹に対する血管内レーザー焼灼術のみで側枝静脈瘤は縮小したが, 完全に消失したのは 一部であった，再発などを考慮すると，さらに長期的な観察が必要であると考えられた。
\end{abstract}

索引用語：下肢静脈瘤, 血管内焼灼術, microphlebectomy, 硬化療法, ablation of saphenous vein

静脈学 $2014 ; 25(4): 386-390$

はじめに

2011 年より波長 $980 \mathrm{~nm}$ レーザーによる血管内 レーザー焼灼術 (endovenous laser ablation; EVLA)が 保険適用となった。従来のストリッピング手術で は鼠径部を含む皮膚切開が必要であったが, EVLA ではこれらの皮膚切開が必要ないことが大きなメ リットとなっている。しかし，いずれの術式でも 伏在静脈不全に伴う側枝静脈瘤に対しては, その

新宿外科クリニック

受付：2013年 9 月 17 日

第 33 回日本静脈学会総会 (2013 年 6 月, 倉敷) 座長推薦演題 doi: 10.7134/phlebol.13-15
径に応じて瘤切除が行われてきた。大量低濃度局 所浸潤麻酔下での瘤切除は皮下出血や感染の合併 症が非使用例と比較し少ないと報告されている が1)，それでも術後出血や神経障害の危険性があ $り^{2}$, 創部の痕が整容的にも問題となる場合があ る。近年では stab avulsion 法により瘤切除も低侵襲 化しているが3)，それでも合併症の危険があること は変わりがない，EVLAによる低侵襲手術において この側枝静脈瘤の瘤切除が省略可能であるかを検 討するために, 伏在型静脈瘤に対するEVLAの 際, 瘤切除を行わなかった症例において, 術前後 の側枝静脈瘤の肉眼的変化, 術前側枝静脈径挹よ び追加治療の有無を検討した。 
Table 1 Demographic data for patients

\begin{tabular}{lc}
\hline No. of patients & 98 \\
No. of limbs & 108 \\
Gender (men:women) & $42: 56$ \\
Mean age (range) & 68.9 y.o. (26-84) \\
CEAP (C2:3:4a:4b:5:6) (limbs) & $56: 32: 20: 0: 0: 0$ \\
Number & \\
GSV & 91 \\
SSV & 17 \\
Mean diameter & \\
$\quad$ GSV & $6.5 \pm 1.5 \mathrm{~mm}$ \\
SSV & $5.9 \pm 1.4 \mathrm{~mm}$ \\
Mean diameter of maximum & $5.4 \pm 2.6 \mathrm{~mm}$ \\
branch varicosity & \\
\hline
\end{tabular}

\section{対象と方法}

2013 年 1 月から 4 月までに一次性伏在型静脈瘤 に対しEVLAを施行し, 側枝静脈瘤の瘤切除や術 中硬化療法などの付加術式を行わなかった症例 98 名 108 肢 (男: 女 $=42: 56$, 平均年齢 68 歳, CEAP 分類 $\mathrm{C} 2: \mathrm{C} 3: \mathrm{C} 4 \mathrm{a}: \mathrm{C} 4 \mathrm{~b}: \mathrm{C} 5: \mathrm{C} 6=56: 32: 20: 0$ : $0: 0$, 大伏在静脈: 小伏在静脈 $=91: 17$ 本, 平均 大伏在静脈径 $6.5 \pm 1.5 \mathrm{~mm}$, 平均小伏在静脈径 $5.9 \pm 1.4 \mathrm{~mm}$, 平均最大側枝静脈径 $5.4 \pm 2.6 \mathrm{~mm}$ ) を対 象とした(Table 1)。診断は超音波装置 $\left(\mathrm{Xario}^{\mathrm{TM}}\right.$, 東 芝メディカルシステムズ)を用い, 全例患者を立位 にして行った。伏在静脈の平均径は伏在静脈深部 静脈接合部より約 $10 \mathrm{~cm}$ 末梢側の部位でかつ瘤化 していない部分で計測した。最大側枝静脈径は伏 在静脈に合流する部位で計測した。原則的に伏在 静脈平均径が $5 \mathrm{~mm}$ 以上の症例を手術適応とした が, 静脈径が $5 \mathrm{~mm}$ 未満でも症状を有し, 患者が手 術を強く希望する場合は手術適応とした。手術は 日帰り手術で行った。全例穿刺アプローチにて光 ファイバーを伏在静脈深部静脈接合部まで挿入 し, 大量低濃度局所浸潤麻酔をエコー補助下に 行った。穿刺は本幹の逆流消失部位より末梢もし くは足関節まで本幹逆流を認める症例は側枝静脈瘤 の合流部末梢で行った、レーザー装置は波長 $980 \mathrm{~nm}$ の半導体レーザー $\left(\mathrm{ELVeS}^{\mathrm{TM}}\right.$ laser, Biolitec Inc.,
Germany)を使用した，光ファイバーを $1.0 \sim 1.5 \mathrm{~mm} /$ 秒の速度で用手的に星引しながら，レーザー出力 は $8 \mathrm{~W}$ で連続照射して伏在静脈を焼灼・閉鎖した。 術後 1 週間後および 2 力月後に診察を行った。弾 性ストッキングは術後 2 カ月間の着用とした。術 後 1 週間後の診察では超音波検査にて伏在静脈の 閉塞, 深部静脈血栓症および endovenous heatinduced thrombus(EHIT)の有無を確認した。2 カ月 後の診察では, 症状改善の問診を行い, 視診にて 側枝静脈瘤の視覚的変化を評価し, 超音波検査に て側枝静脈瘤の径を測定した。

視診で側枝静脈瘤が完全に消失した群(完全縮小 群)，縮小はしたが残存する群(部分縮小群)および 術前と変化を認めない群(無変化群)の 3 群に分類 した。ささに問診にて症状の有無を確認し, 症状 もしくは整容的な理由から追加治療が必要な場合 は硬化療法を行った。

\section{結 果}

平均大伏在静脈焼灼長 $39.2 \pm 12.8 \mathrm{~cm}$, 平均小伏在 静脈焼灼長 $17.0 \pm 4.1 \mathrm{~cm}$ であった。

合併症は深部静脈血栓症 0 例 $(0 \%)$, 血栓性静脈 炎 4 例 (3.7\%), EHIT class 1, 4 例 (3.7\%), class 2, 5 例 (4.6\%), class 3, 3 例 (2.8\%)であった。

側枝静脈瘤の完全縮小群は 11 肢 $(10.2 \%)$, 部分 縮小群は 97 肢 $(89.8 \%)$, 無変化群は 0 肢 $(0 \%)$ だっ た，術後に症状が残存した症例は認めず，整容的 に不満足であった症例は 7 肢 $(6.5 \%)$ であり，その 全例に硬化療法を追加した (Fig. 1).

なお, 各群の術前最大側枝静脈径は完全縮小群 で $5.0 \pm 2.2 \mathrm{~mm}$, 部分縮小群で $6.1 \pm 2.3 \mathrm{~mm}$, 硬化療 法追加例で $3.5 \pm 1.1 \mathrm{~mm}$ であった(Table 2).

また, 術前および術後 2 力月時点で側枝径の工 コーでの計測が可能であったのは 66 肢であった そのうち術後側枝径が縮小した症例 59 肢では術前 と比較し平均 $42.8 \%$ 径が縮小し, 不変症例は 2 肢, 側枝が拡張した症例は 5 肢であり, 術前と比 較し 7.0\%の径の拡大を認めた(Table 3). 一方で, エコー計測での側枝縮小症例 59 肢のうち視診での 完全縮小群, 部分縮小群, 無変化群の比率は $8: 43$ : 8 , 径の不変群 2 症例では $0: 1: 1$, 径拡大群 5 症例 


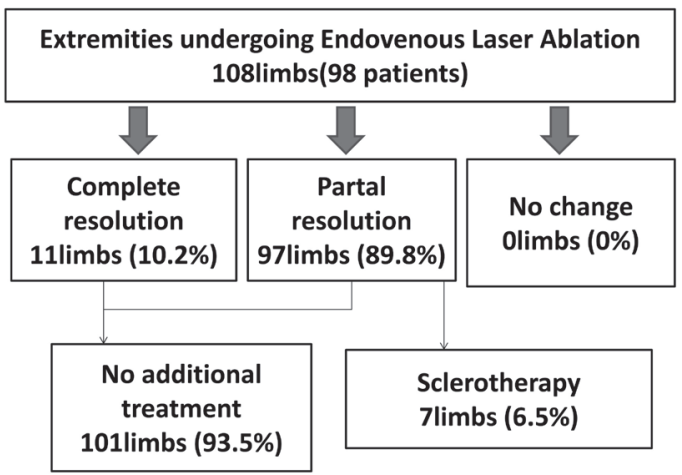

Table 2 Preoperative maximum diameter of branch varicosities

\begin{tabular}{ll}
\hline Total limbs & $5.4 \pm 2.6 \mathrm{~mm}$ \\
Complete resolution & $5.0 \pm 2.2 \mathrm{~mm}$ \\
Partial resolution & $6.1 \pm 2.3 \mathrm{~mm}$ \\
Limbs with additional sclerotherapy & $3.5 \pm 1.1 \mathrm{~mm}$ \\
\hline
\end{tabular}

Fig. 1 Flowchart of patient outcomes.

Table 3 Change of the size of branch varicose veins after endovenous laser ablation

\begin{tabular}{lccc}
\hline & Number & $\begin{array}{c}\text { Change rate } \\
(\%)\end{array}$ & $\begin{array}{c}\text { Ratio of complete resolution, } \\
\text { partial resolution and no change }\end{array}$ \\
\hline Reduction & 59 & -42.8 & $(8: 43: 8)$ \\
No change & 2 & 0 & $(0: 1: 1)$ \\
Enlargement & 5 & 7.0 & $(1: 1: 3)$ \\
\hline
\end{tabular}

では $1: 1: 3$ であった

考察

静脈高血圧によって拡張・蛇行した下腿の側枝静 脈が, 不全のある伏在静脈本幹の治療で縮小する こと出や出産後の静脈圧の低下によって径や形態が 正常化すること音は以前から知られている。 した がって, 伏在型静脈瘤において伏在静脈本幹の逆 流を阻止するだけでも側枝静脈瘤が縮小し，追加 治療が不必要になる可能性が示唆される. 従来, 伏在型静脈瘤の治療は比較的侵襲の大きいスト リッピング手術が中心であったため,この側枝静 脈瘤治療の必要性の有無に関してはあまり注目さ れていなかった。しかし，近年，EVLA やラジオ波 による血管内焼灼術 (radiofrequency ablation; RFA)に よる低侵襲の日帰り手術が広く普及するに伴い, 側枝静脈瘤の治療の必要性の有無が検討されるよ うになっている。

Schanzer は 76 名 86 肢の伏在型静脈瘤に EVLA を施行し, 術後 1 力月目の時点で側枝静脈瘤が完
全に縮小したのが 36 肢 (41.8\%), 部分縮小が 48 肢

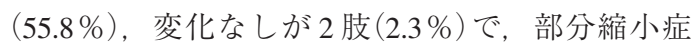
例のうち 36 肢 $(41.8 \%)$ で 2 期的な側枝静脈瘤の治 療が必要であり, そのうち 23 肢 $(26.7 \%)$ に瘤切除 あるいは硬化療法による追加療法を施行したと報 告している6). Welchは181肢の伏在型静脈瘤に RFA を施行し, 術後 2 3 カ月目の時点で追加治療 の必要性から 44 肢 $(29.7 \%$ ) に瘤切除あるいは硬化 療法を施行したと報告している7). Monahan は伏在 型静脈瘤にRFA を施行し, 術後 6 力月経過観察可 能であった 31 名 39 肢の側枝 222 本に扔いて, 側 枝静脈瘤が本幹治療のみで完全に縮小したのは全 側枝の $28.4 \%(63 / 222)$, 残りの側枝の $88.7 \%$ (141/159) では血管径の約 $34.6 \%$ の部分縮小を認 め, 6.3\% (10/159)では変化なし， $2.5 \%(4 / 159)$ では むしろ平均 $1.3 \mathrm{~mm}$ の側枝径の拡張を認めたと報告 している. Monahanの検討で硬化療法を追加した のは全側枝の $10.4 \%(23 / 222)$ であった ${ }^{8)}$.

これらの報告で伏在静脈本幹の治療のみで側枝 静脈瘤の縮小, 消失が認められたが, 約 10〜30\% 
で追加治療が必要であった。

一方, 今回の検討では 伏在静脈本幹の EVLA 単 独では術後 2 カ月の時点で視診上, 側枝静脈瘤が 縮小し完全に認められなくなったのは $10.2 \%$ み であり， $89.8 \%$ では部分縮小にとどまった。術後 2 カ月の時点で追加硬化療法が必要であったのは全 体の $6.5 \%$ のであった。術後に硬化療法を追加し た症例は整容的要望の強い症例であったが, 硬化 療法追加例における術前の最大側枝静脈径は必ず しも静脈径の大きい症例ではなかった。一方, 2 力 月の時点で超音波評価可能であった 66 肢のうち,

59 肢で術前の $42.8 \%$ の側枝の縮小を認め, 無変化 群 2 肢, 側枝拡大群は 5 肢であった。しかしなが らこれらの径の縮小および拡大の程度と視診での 完全縮小群, 部分縮小群, 無変化群といった結果 とが一部の症例で乘離する結果となった。このこ とから側枝静脈瘤が肉眼的に残存した場合に追加 治療が必要になるかは患者個々の治療目的による と思われた。

EVLA や RFA で伏在静脈本幹の治療のみを行い 側枝静脈瘤の治療を 2 期的に行う方法のメリット としては, 治療時間が短縮され手術創を減らせる ことが挙げられる。皮膚炎を合併している患者で は創部が治癒しにくく，抗血小板剂や抗凝固剤を 内服している患者では術後出血の危険性があるた め，できるだけ皮膚切開は避けるべきである。

よってこれらの症例には本法は有効であると考え られる。

しかし，2 期的に瘤切除あるいは硬化療法を行え ば側枝静脈瘤の治療は可能であるが, 2 期的治療は 全治療期間の延長につながり, 硬化療法による色 素沈着や血栓性静脈炎などの合併症9)がある. 今回 の検討でも追加硬化療法が必要な症例があったよ うに, すべての症例で側枝静脈瘤が消失するわけ ではなく，整容的改善が不満足に終わることもあ る.したがって, 伏在型静脈瘤に対し伏在静脈本 幹の治療のみを行い側枝静脈瘤の治療を 2 期的に 行う治療は, 患者にとって不満足な結果に終わる 可能性があり, 術前に側枝静脈瘤の治療を 1 期的 に行わない際のメリットとデメリットを患者に十 分に説明すべきであると考えられた。
今回の検討では他の報告と比較し, 側枝静脈瘤 の追加治療が必要になる症例の割合が少なかっ た、その理由として，われわれの症例では男女比 が 42 対 56 と, 男性の割合が比較的高かったこと が考えられる。一般的に下肢静脈瘤は女性の方が 有病率が高いが，当院は日帰り手術専門クリニッ クであり男性に多い疾患である鼠径ヘルニアも取 り扱っているため, 男性患者が多かったと考えら れた。また，今回，術後の観察期間が約 2 力月と 短期間であった。硬化療法の必要性を判断した術 後 2 カ月の時点まで弾性ストッキングの着用を 行っていたため, 症状が軽減していた可能性もあ り，着用中止後の症状の経過も評価すべきであっ た。 また，手術数年後の静脈瘤再発症例は日常診 療ではしばしば経験することであり，術後 2 力月 後で長期的に側枝静脈瘤が消失したとの判断は難 しいとも思われる。したがって，今後はさらに長 期間観察を行って再発の有無も考慮したうえで, 瘤切除の必要性を検討すべきであると考えられた。

\section{結 語}

伏在静脈本幹に対する EVLA のみで術後 2 力月 の時点で多くの症例で側枝静脈瘤は縮小したが, 側枝静脈瘤が完全に消失したのは一部であった。2 カ月という観察期間は短いと考えられ，長期経過 後の再発などを考慮すると, さらに長期的な観察 が必要であると考えられた。

\section{利益相反}

著者全員が利益相反はない.

\section{文献}

1) Keel D, Goldman MP: Tumescent anesthesia in ambulatory phlebectomy: addition of epinephrine. Dermatol Surg 1999; 25: 371-372

2) Kundu S, Grassi CJ, Khilnani NM, et al: Multi-disciplinary quality improvement guidelines for the treatment of lower extremity superficial venous insufficiency with ambulatory phlebectomy from the Society of Interventional Radiology, Cardiovascular Interventional Radiological Society of Europe, American College of Phlebology and Canadian Interventional Radiology Association. J Vasc Interv Radiol 2010; 21: 1-13 
3) Goren G, Yellin AE: Ambulatory stab evulsion phlebectomy for truncal varicose veins. Am J Surg 1991; 162: 166-174

4) Fegan WG: Continuous compression technique of injecting varicose veins. Lancet 1963; 2: 109-112

5) Boivin P, Cornu-Thenard A, Charpak Y: Pregnancyinduced changes in lower extremity superficial veins: an ultrasound scan study. J Vasc Surg 2000; 32: 570-574

6) Schanzer H: Endovenous ablation plus microphlebectomy/ sclerotherapy for the treatment of varicose veins: single or two-stage procedure? Vasc Endovascular Surg 2010; 44:
545-549

7) Welch HJ: Endovenous ablation of the great saphenous vein may avert phlebectomy for branch varicose veins. J Vasc Surg 2006; 44: 601-605

8) Monahan DL: Can phlebectomy be deferred in the treatment of varicose veins? J Vasc Surg 2005; 42: 1145-1149

9) Guex JJ, Schliephake DE, Otto J, et al: The French polidocanol study on long-term side effects: a survey covering 3,357 patient years. Dermatol Surg 2010; 36 (Suppl 2): 993-1003

\section{Abstract \\ The Size Reduction in Visible Varicosities after Endovenous Laser Ablation for Insufficient Saphenous Vein}

Tomoko Hirabayashi, Seiichi Sano, and Itaru Takashima

Shinjuku Surgical Clinic

Key words: varicose veins, endovenous ablation, microphlebectomy, sclerotherapy, ablation of saphenous vein

Objective: This study was designed to assess the necessity of treatment of branch varicose veins after endovenous laser ablation (EVLA) for insufficient saphenous vein. Methods: From January to March 2013, 98 patients (108 limbs) with primary varicose veins for the insufficient saphenous vein (91 great saphenous vein (GSV) and 17 small saphenous vein (SSV), 42 men and 56 women, mean age 68 years old, mean GSV diameter $6.5 \pm 1.5 \mathrm{~mm}$, mean SSV diameter $5.9 \pm 1.4 \mathrm{~mm}$, mean diameter of maximum branch varicose vein $5.4 \pm 2.6 \mathrm{~mm}$ ) underwent EVLA without concomitant microphlebectomy or sclerotherapy. We evaluated improvement of symptoms and size reduction in visible varicosities 2 months after operation. Results: Mean length of ablated GSV and SSV were $39.2 \pm$ $12.8 \mathrm{~cm}$ and $17.0 \pm 4.1 \mathrm{~cm}$, respectively. A complete resolution of branch varicose vein was found in 11 limbs (10.2\%), reduction in size in 97 limbs (89.8\%), and no change in no limb. Additional sclerotherapy for branch varicose veins was needed in 7 limbs (6.5\%) for cosmetic reason. Conclusion: EVLA alone for the insufficient shapenous vein result in improvement of symptoms and visible varicosities regression in more than half of the cases at two months after EVLA. However, complete resolution could be seen in only a few cases. Further observation will be needed to evaluate the necessity of treatment of branch varicosities.

Jpn J Phlebol 2014; 25 (4): 386-390 